\title{
Katastrofik Sağlık Harcaması: Literatür Taraması
}

\section{Altuğ Murat KÖKTAŞ ${ }^{1}$}

\section{Ahmet Arif EREN ${ }^{2}$}

\section{ARTICLE INFO}

Article History:

Date Submitted: 08.06.2017

Date Accepted: 01.08.2017

JEL Classification:

I14

I31

132

Keywords:

Catastropic

Health Expenditure

\begin{abstract}
Genel olarak herhangi bir sağlık finansman sisteminin üç temel amacı bulunmaktadır. Bunlar, Tüketicileri, sağlık harcamalarının finansal riskinden korumak, sağlık hizmetleri sunumunda etkinlik ve tüketici ve hizmet sunucu arasında adil olmak (Ellis ve McGuire, 1993: 138) şeklinde sıralanmaktadır. Sağlık sisteminde reform düşüncesiyle ortaya atılan maliyet paylaşımı, söz konusu finansman amaçları arasında çatışmaya neden olmaktadır. Sonuç olarak maliyet paylaşımı düşüncesi ile ortaya çıkan cepten harcama yöntemi, en adaletsiz ve en etkinsiz olanı (Wagstaff, 1989; Xu vd., 2003) olarak görülmektedir.
\end{abstract}

\footnotetext{
${ }^{1}$ Niğde Ömer Halisdemir Üniversitesi, İktisadi ve İdari Bilimler Fakültesi, Maliye Bölümü Öğretim Üyesi, altugmkoktas@gmail.com

${ }^{2}$ Niğde Ömer Halisdemir Üniversitesi, İktisadi ve İdari Bilimler Fakültesi, Maliye Bölümü Öğretim Üyesi, ahmetarif74@gmail.com
} 
Genel olarak herhangi bir sağlık finansman sisteminin üç temel amacı bulunmaktadır. Bunlar, Tüketicileri, sağlık harcamalarının finansal riskinden korumak, sağlık hizmetleri sunumunda etkinlik ve tüketici ve hizmet sunucu arasında adil olmak (Ellis ve McGuire, 1993: 138) şeklinde sıralanmaktadır. Sağlık sisteminde reform düşüncesiyle ortaya atılan maliyet paylaşımı, söz konusu finansman amaçları arasında çatışmaya neden olmaktadır. Sonuç olarak maliyet paylaşımı düşüncesi ile ortaya çıkan cepten harcama yöntemi, en adaletsiz ve en etkinsiz olanı (Wagstaff, 1989; Xu vd., 2003) olarak görülmektedir.

Talep yanlı maliyet sınırlama yöntemi olarak maliyet paylaşımının, hizmet sunumunda eşitliği bozucu sonuçlara yol açtığı kabul edilmektedir. Talep yanlı maliyet paylaşımı şayet sağlık hizmetleri tüketimini azaltmak için kullanılacaksa bu durum, tüketicilere ilave finansal riskler yükleyecektir (Ellis ve McGuire, 1993: 137). Maliyet paylaşımı sonucu ortaya çıkan finansal yükün düşük gelirliler tarafından taşınması potansiyeli nedeniyle finansmanda, yaşl1, genç ve kronik hastaların sağlık hizmetlerine erişimini azaltarak, bu hizmetlerin kullanımında hakkaniyetsizliğe neden olabilmektedir (Saltman ve Figueras, 1998: 85-90). Temel mantığ1 hizmet sunumuna yönelik talebi kısmak olan maliyet paylaşımı, özellikle düşük gelirlilerin hizmet talebini düşürmektedir (Robinson, 2002: 177; Scheiber ve Maeda, 1997). Benzer biçimde söz konusu maliyet paylaşımının işsiz ve evsizlerin sağlığını olumsuz yönde etkilediği de bilinmektedir (Rubin ve Mendelson, 1996). Diğer yandan maliyet paylaşımının bulunmadığı durumlarda dahi, Slovenya, Litvanya, Macaristan ve Çek Cumhuriyeti gibi ülkelerde, sigorta kapsamı dışında olan sağlık hizmetleri nedeniyle, yüksek miktarda özel sağlık harcamasının varlığı raporlanmıştır. Hizmetlerin bedava sunulması, bireyleri özel harcamalardan korumamaktadır (WB, 2008: 7). Bu bağlamda bireylerin katastrofik sağlık harcamalarına maruz kaldığı ileri sürülebilir.

Dünyada her yıl milyonlarca insan, sağlık hizmetlerinden yararlanabilmek için, ödeme güçlerinin zayıf olması nedeniyle finansal sorun yaşamaktadır. Aynı zamanda bu durum, kişilerin çalışamayacak kadar hasta olmaları nedeniyle katastrofiye ve nihayetinde yoksullaşmaya neden olmaktadır. Bununla birlikte söz konusu etki yalnızca düşük gelir gruplarında değil, yüksek gelir gruplarında dahi görülebilmektedir (Xu vd., 2007: 972-973). Berki'ye göre katastrofi (1986: 138) "Hanelerin alışagelmiş harcamalarını ve yaşam seviyelerini tehlikeye atan harcamalardır... Bu bağlamda finansal katastrofi, cepten yapılan 
sağlık harcamasının, hane gelirinin belirli bir oranına erişmesi” biçiminde tanımlanmaktadır. Van Doorslaer ve diğerleri ise katastrofik sağlık harcamalarını (2007: 1169) "Hanelerin yaşam standartlarını bozan ve genellikle kendi kaynaklarıyla finanse edilen harcamalar" olarak tanımlamaktadır. Bu durumda katastrofi, hanehalkı refahındaki değişme olarak ifade edilebilir (Naga ve Lamiraud, 2008: 3). Xu ve diğerlerine göre ise (2003: 111), "Sağlık hizmetlerine erişim, bireyleri gelirlerinin belirli düzeyinde katastrofik harcama yapmaya zorlamakta ve böylece onları yoksulluğa sürüklemektedir”. Katastrofik sağlık harcaması ve yoksullaşma, sağlık hizmetlerinde görülen cepten harcamalarla yakın ilişkilidir. Whitehead ve diğerleri (2001) bu durumu "özel ve kamusal sağlık hizmet sunucularına erişim için yapılan cepten harcamalarda meydana gelen artış, haneleri yoksulluğa iterken, yoksulları daha da yoksullaştırmaktadır” biçiminde ifade etmektedir.

Katastrofik sağlı harcaması, yalnızca sağlı hizmetlerinin yüksek maliyetlerinden kaynaklanmamaktadır. Göreli olarak düşük miktarlı bir sağlık harcaması dahi yoksul haneleri gıda, konut ya da eğitim gibi temel nitelikli harcamaları kısmaya zorlayarak katastrofiye neden olabilmektedir (Xu vd., 2007: 973, Xu vd., 2003: 111, Van Doorslaer vd., 2007: 1170). Örneğin 5.000 \$'lık hastane ücreti, hanenin tam kapsamlı bir sağlık sigortasına sahip olması veya yıllık gelirinin 100.000 \$'1 bulması durumunda katastrofiye yol açmazken, söz konusu gelirin yıllık 15.000 \$ olması ve herhangi bir sağlık sigortasının bulunmaması, finansal katastrofiye neden olmaktadır (Berki, 1986: 138-139). Bu bağlamda, belirli bir dönemde hanelerin sağlık hizmetlerini finanse edebilmek için temel harcamalarını kısması ya da cepten yapılan harcamaların toplam hane harcamaları veya geliri içindeki payının kritik bir eşiğe ulaşması, "katastrofi" olarak ifade edilmektedir (Xu vd., 2003: 111; Naga ve Lamiraud, 2008: 2, Berki, 1986: 138; Russel, 2004; Wagstaff ve Van Doorslaer, 2003; Wyszewianski, 1986: 382; Xu vd., 2007: 973, Doorslaer vd., 2007: 1169; Gotsadze, 2009). Söz konusu ifade, sağlık harcamalarının hanehalkı bütçesi içerisinde geniş bir yer tutmasıyla ilişkilendirilmektedir. $\mathrm{Bu}$ yükün mevcut hane tüketiminin kısılması veya borç ve tasarruf yoluyla finanse edilmesi durumunda, haneler katastrofiye uğramaktadır (O’Donnell vd., 2008: 203).

Hane tüketimi içerisindeki payı itibariyle katastrofiye neden olan oranın ne düzeyde olacağı üzerinde literatürde bir uzlaşma bulunmamaktadır (Xu vd., 2003: 111; Naga ve Lamiraud, 2008: 2). Bazı çalışmalar kritik eşik olarak hane gelirlerinin \%5'ini alırken (Berki, 
1986), bazıları ise \%10 (Waters vd., 2004) ve \%20 (Wyszewianski, 1986) değerini referans almışlardır. Bununla birlikte literatürde genellikle sağlık harcamalarının toplam hane harcamaları içindeki payının \%10’u, katastrofik sağlık harcaması olarak değerlendirilmektedir. Bunun nedeni, \%10 eşiğinin haneleri diğer temel ihtiyaçlarından vazgeçmeye zorlaması, üretken varlıklarını satması, borçlanmaya yöneltmesi ya da yoksullaştırmasıdır (Van Doorslaer vd., 2007: 1170; Russell, 2004: 9). Dünya Bankası yazarları ise farklı bir yöntemle, eşik değer olarak hanelerin ödeme kapasitelerinin \%40'ını dikkate almışlardır (Xu vd., 2003, Xu vd., 2007). Buna göre ödeme kapasitesi, "hanelerin temel ihtiyaçlarını karşılamak için yaptıkları harcamalardan geriye kalan harcamalar" olarak tanımlanmaktadır. Söz konusu temel ihtiyaçlar ise literatürde genellikle, gıda harcamaları medyan değerinin \%50'si olarak kabul edilmektedir. Bununla birlikte değerlendirme hatasını en aza indirmek amacıyla gıda harcaması, toplam harcamalar içindeki gıda harcamasının \%45 ve \%55'lik dilimler arasında bulunan hanelerin eşdeğer fert başına gıda harcamasının ortalaması olarak ifade edilmektedir. Bu bağlamda cepten yapılan sağlık harcamalarının ödeme kapasitesinin \%40'ını aşması, katastrofi olarak kullanılmaktadır. Hane geliri yerine efektif geliri dikkate alan ödeme kapasitesi, hanelerin borçlanma yeteneklerini göz önünde bulundurmaktadır. Bunun nedeni ise, gelirin konjonktürel şoklara maruz kalırken, tüketimin ise daha dengeli bir seyir izlemesidir (Xu vd., 2007: 973; Xu vd., 2003: 112). 